\title{
Pengembangan Sistem Deteksi Kantuk Menggunakan Pengklasifikasi Random Forest pada Sinyal Elektrokardiogram
}

\author{
(Development of Drowsiness Detection System Using Random Forest \\ Classifier on Electrocardiogram Signals)
}

\author{
Nuryani Nuryani ${ }^{1}$, Khoirun Nisak $^{1}$, Artono Dwijo Sutomo ${ }^{1}$
}

\begin{abstract}
Drowsiness is one of the main causes of accidents in traffic, manufacturing industry, and other fields. A system that can detect sleepiness early is important to reduce the number of accidents due to drowsiness. Changes in autonomous nervous activity associated with drowsiness were analyzed using heart rate variability (HRV) obtained from ECG. The Random Forest classifier is known to perform well and is strong against overfitting. In this study, a drowsiness detection system was developed based on electrocardiogram (ECG) signals and Random Forest. The drowsiness detection system was trained using ECG recordings from DROZY database equipped with Karolinska Sleepiness Scale (KSS). The system input features were extracted based on time domain and frequency domain methods. Drowsiness levels were classified based on simplified KSS: drowsy and awake. Random Forest was validated using the Out-of-Bag (OOB) method. The effects of the number of estimators and max features variations were evaluated. The features were sorted based on their importance and combined for the system input with various ECG segmentation lengths. The best performance of the drowsiness detection system was with an average accuracy of $94.61 \%$, sensitivity of $96.67 \%$, and specificity of $91.67 \%$ from $40 \mathrm{~s}$ segmentations.
\end{abstract}

Intisari-Kantuk merupakan salah satu penyebab utama kecelakaan dalam lalu lintas, industri manufaktur, maupun pada bidang lain. Untuk itu, sistem yang dapat mendeteksi kantuk secara dini merupakan hal yang sangat penting dalam rangka mengurangi angka kecelakaan akibat kantuk. Kantuk dapat dianalisis melalui Heart Rate Variability (HRV) dari sinyal EKG yang menunjukkan perubahan aktivitas saraf otonom. Pengklasifikasi Random Forest diketahui berkinerja sangat baik serta kuat terhadap overfitting. Oleh karena itu, pada makalah ini dikembangkan sistem deteksi kantuk menggunakan sinyal elektrokardiogram (EKG) dan Random Forest. Sistem deteksi kantuk dilatih menggunakan rekaman EKG dari database DROZY yang dilengkapi Karolinska Sleepiness Scale (KSS). Fitur masukan sistem diekstraksi berdasarkan metode ranah waktu dan ranah frekuensi. Tingkat kantuk diklasifikasikan berdasarkan KSS yang disederhanakan menjadi dua kelas, yaitu kantuk dan terjaga. Random Forest divalidasi dengan metode Outof-Bag (OOB). Efek dari variasi jumlah estimator dan max feature terhadap kinerja sistem dievaluasi. Fitur diurutkan berdasarkan kepentingannya dan dikombinasikan sebagai masukan sistem dengan berbagai panjang segmentasi EKG. Kinerja terbaik sistem deteksi kantuk yaitu rata-rata akurasi $94,61 \%$, sensitivitas

${ }^{1}$ Program Studi Fisika, F. MIPA, Universitas Sebelas Maret, Jl. Ir. Sutami 36A, Surakarta, INDONESIA (Tlp: 0271-669017; e-mail: nuryani@mipa.uns.ac.id)
96,67\%, dan specificity 91,67\%, yang diperoleh dengan segmentasi 40 detik.

Kata Kunci--Kantuk, Elektrokardiogram, KSS, Random Forest.

\section{Pendahuluan}

Kematian dan luka akibat kecelakaan lalu lintas menjadi masalah yang serius secara global. Menurut data Global Status Report on Road Safety 2018, angka kematian akibat kecelakaan lalu lintas terus bertambah, mencapai 1,35 juta jiwa pada tahun 2016 [1]. Kantuk merupakan salah satu penyebab meningkatnya risiko kecelakaan lalu lintas. AAA Foundation for Traffic Safety telah melakukan survei pada lebih dari 14.000 kecelakaan dari tahun 2009 hingga 2013 dan memperkirakan bahwa kantuk terlibat dalam $21 \%$ kecelakaan fatal di Amerika [2].

Kantuk didefinisikan sebagai keadaan ketika kesadaran terganggu karena kecenderungan untuk tidur [3]. Kinerja mengemudi yang tidak stabil sering terjadi pada pengemudi dalam keadaan mengantuk [2]. Tingkat kantuk dapat dikelompokkan berdasarkan Karolinska Sleepiness Scale (KSS) [4]. Dengan skala KSS, subjek berada pada tingkatan yang mencerminkan kondisi psikofisik yang dirasakan [5].

Keadaan kantuk dan terjaga berkorelasi dengan aktivitas saraf otonom simpatetik dan parasimpatetik tubuh. Keadaan terjaga ditunjukkan dengan meningkatnya aktivitas simpatetik dan/atau menurunnya aktivitas parasimpatetik. Aktivitas saraf otonom dapat dianalisis menggunakan Heart Rate Variability (HRV) dari sinyal elektrokardiogram (EKG) [6]. Analisis HRV tersebut dapat dilakukan, baik pada ranah waktu maupun ranah frekuensi [7]. EKG merupakan rekaman dari aktivitas listrik yang dihasilkan oleh sel jantung yang mencapai permukaan tubuh [8].

Beberapa penelitian mengenai deteksi kantuk menggunakan sinyal EKG telah dilakukan sebelumnya, di antaranya menggunakan analisis diskriminan linier [6], jaringan Saraf Tiruan (JST) dengan Radial Basis Function (RBF) [9], dan JST-RBF dengan optimasi menggunakan Particle Swarm Optimization (PSO) [10].

Pada makalah ini dipaparkan sistem deteksi kantuk menggunakan Random Forest. Dipilihnya Random Forest pada sistem deteksi ini adalah karena keunggulan-keunggulan yang dimiliki oleh Random Forest, di antaranya unggul dalam penanganan overfitting. Overfitting merupakan masalah yang banyak terjadi pada machine learning. Di samping itu, Random Forest juga belum banyak dieksplorasi untuk sistem deteksi kantuk, khususnya yang menggunakan EKG. Random Forest 


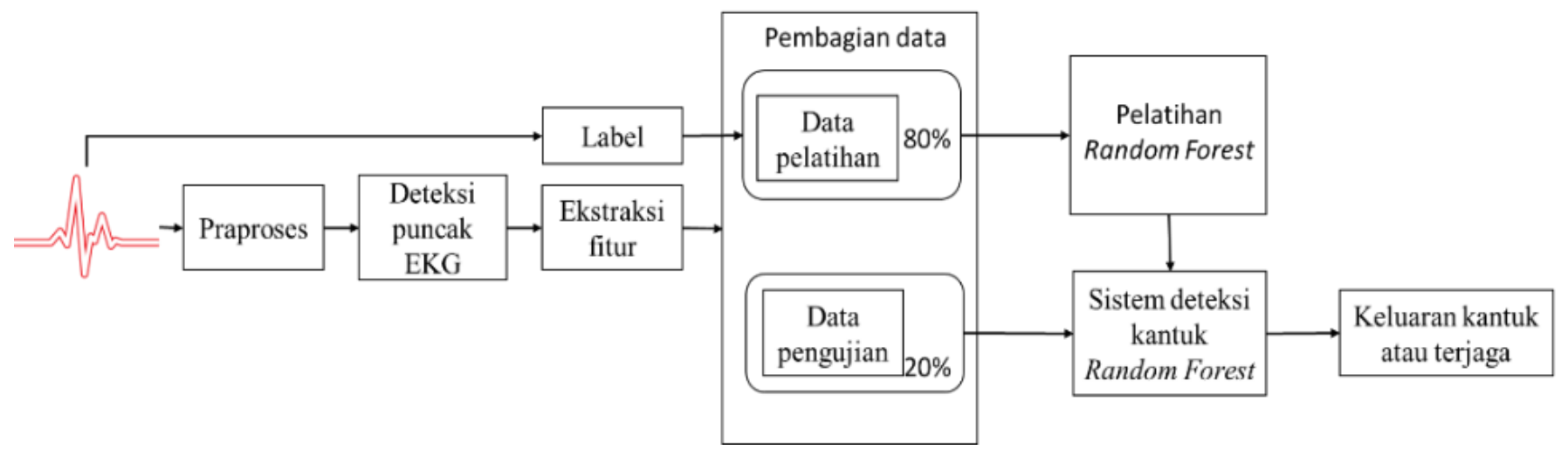

Gbr. 1 Rancangan pengembangan sistem deteksi kantuk.

tersusun dari sejumlah decision tree. Random Forest diketahui berkinerja sangat baik dibandingkan dengan banyak pengklasifikasi lainnya serta kuat terhadap overfitting [11]. Pada makalah ini digunakan fitur EKG pada ranah waktu dan ranah frekuensi.

\section{Metodologi}

Metode untuk deteksi kantuk menggunakan EKG dan Random Forest ditunjukkan pada Gbr. 1, yang menjelaskan proses pengembangan sistem deteksi kantuk. Dalam metode ini ada beberapa tahap, yaitu praproses, ekstraksi fitur, pelatihan Random Forest, dan pengujian sistem.

\section{A. Persiapan Data}

Data rekaman EKG dari partisipan kantuk/terjaga terdiri atas 34 rekaman. Tiap rekaman memiliki durasi 600 detik dengan sampling rate $512 \mathrm{~Hz}$. Rekaman EKG dilengkapi dengan tingkat kantuk berdasarkan KSS. Pada makalah ini, tingkat kantuk disederhanakan menjadi dua tingkat, yaitu keadaan kantuk dengan skala KSS 1-5 dan keadaan terjaga dengan skala KSS 6-9. Deskripsi skala 5 pada KSS yaitu "tidak terjaga dan tidak kantuk" sedangkan pada skala 6 KSS yaitu "muncul tanda mengantuk" sehingga skala 5 dan 6 dapat dijadikan batasan antara kelas terjaga dan kantuk. Tingkat kantuk digunakan sebagai target keluaran atau label pada pelatihan Random Forest. Data EKG yang digunakan adalah seperti yang digunakan pada penelitian sebelumnya [12], yaitu $U L g$ Multimodality Drowsiness Database atau dinamai dengan database DROZY. Rincian rekaman EKG yang digunakan pada makalah ini disajikan pada Tabel I, yang menunjukkan bahwa diperoleh dua puluh rekaman kelas kantuk dan empat belas rekaman kelas terjaga.

\section{B. Praproses}

Tahap praproses pengolahan EKG adalah tahap pertama sebelum tahap ekstraksi fitur. Pada tahap praproses dilakukan segmentasi, filtrasi, deteksi R-peaks, dan analisis spektrum dengan metode Welch. Tiga macam panjang segmen diteliti, yaitu 20 detik, 30 detik, dan 40 detik. Jumlah segmen adalah 1.020 segmen untuk segmentasi 20 detik, 680 segmen pada segmentasi 30 detik, dan 510 segmen pada segmentasi 40 detik. Proses filtrasi dilakukan untuk mengurangi noise yang sering terjadi pada data mentah EKG. Filter yang digunakan adalah
TABEL I

RINCIAN REKAMAN EKG YANG DIGUNAKAN

\begin{tabular}{|c|c|c|c|c|c|}
\hline Rekaman & KSS & Label & Rekaman & KSS & Label \\
\hline 1-1.edf & 3 & 0 & 7-3.edf & 9 & 1 \\
\hline 1-2.edf & 6 & 1 & 8-1.edf & 2 & 0 \\
\hline 1-3.edf & 7 & 1 & 8-2.edf & 6 & 1 \\
\hline 2-2.edf & 7 & 1 & 8-3.edf & 8 & 1 \\
\hline 2-3.edf & 6 & 1 & 9-2.edf & 6 & 1 \\
\hline 3-1.edf & 2 & 0 & 9-3.edf & 8 & 1 \\
\hline 3-2.edf & 3 & 0 & 10-1.edf & 3 & 0 \\
\hline 3-3.edf & 4 & 0 & 10-3.edf & 7 & 1 \\
\hline 4-1.edf & 4 & 0 & 11-1.edf & 4 & 0 \\
\hline 4-2.edf & 8 & 1 & 11-2.edf & 7 & 1 \\
\hline 4-3.edf & 9 & 1 & 11-3.edf & 7 & 1 \\
\hline 5-1.edf & 3 & 0 & 12-1.edf & 2 & 0 \\
\hline 5-2.edf & 7 & 1 & 13-1.edf & 6 & 1 \\
\hline 5-3.edf & 8 & 1 & 13-2.edf & 3 & 0 \\
\hline 6-2.edf & 3 & 0 & 14-1.edf & 5 & 0 \\
\hline 6-3.edf & 7 & 1 & 14-2.edf & 7 & 1 \\
\hline 7-2.edf & 4 & 0 & 14-3.edf & 8 & 1 \\
\hline
\end{tabular}

filter Finite Impulse Response (FIR). Selanjutnya, dicari $R$ peaks EKG (puncak gelombang QRS) menggunakan pendekatan Hamilton [13]. R-peaks yang diperoleh digunakan sebagai dasar untuk menghitung Normal-to-Normal Interval (NNI), Heart Rate (HR) dan Power Spectral Density (PSD). NNI merupakan jarak antara dua $R$-peaks yang berurutan, sedangkan PSD dihitung dari NNI menggunakan metode Welch. Pita frekuensi dibagi pada batasan Very Low Frequency (VLF) $(0,00 \mathrm{~Hz}-0,04 \mathrm{~Hz})$, Low Frequency (LF) $(0,04 \mathrm{~Hz}-$ $0,15 \mathrm{~Hz})$, dan High-Frequency (HF) $(0,15 \mathrm{~Hz}-0,40 \mathrm{~Hz})$.

\section{Ekstraksi Fitur}

Perbedaan panjang NNI pada EKG terjaga dan kantuk menjadi dasar untuk ekstraksi fitur. Pita LF berkorelasi dengan aktivitas simpatetik dan pita HF berkorelasi dengan aktivitas parasimpatetik pada analisis HRV [6], sehingga analisis ranah frekuensi ini digunakan sebagai fitur.

PSD atau spectral power mewakili kekuatan sinyal masukan pada suatu rentang frekuensi. Perhitungan PSD berdasarkan 

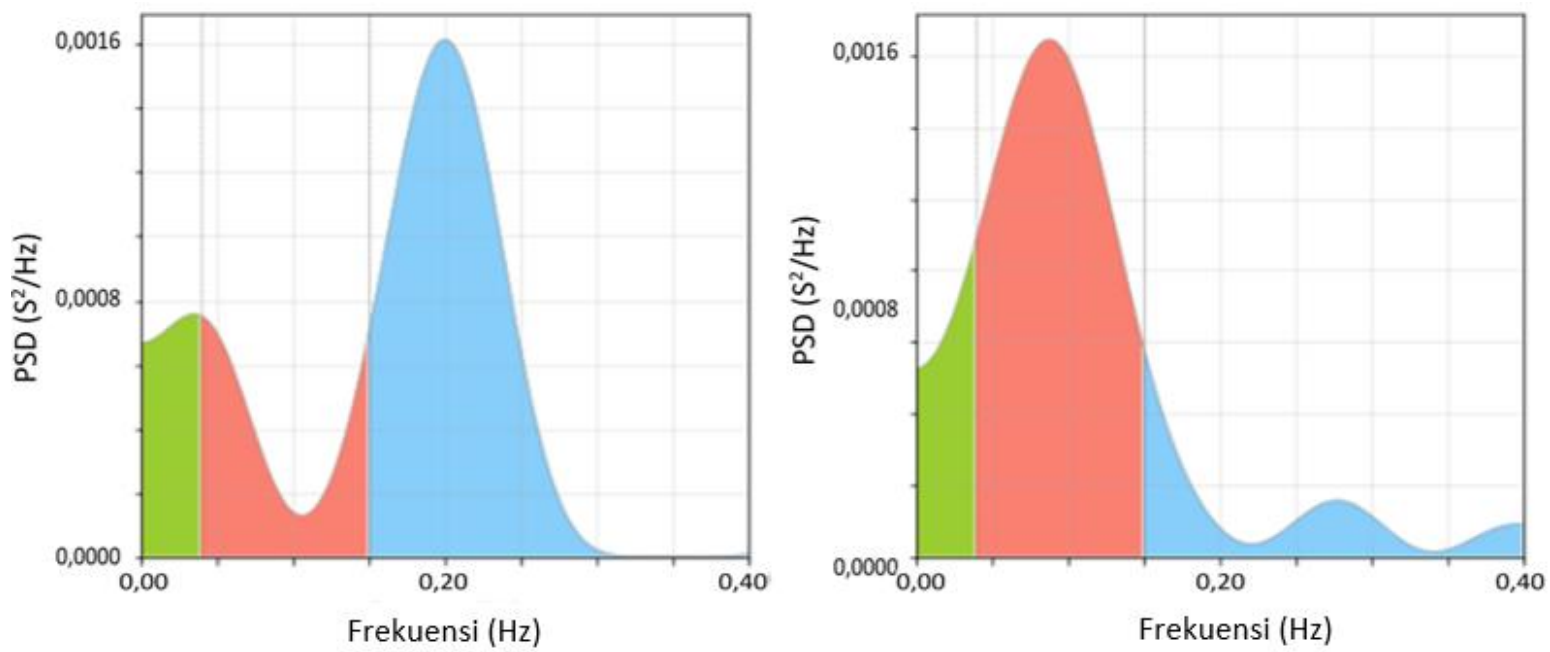

Gbr. 2 Grafik PSD rekaman, (a) kelas kantuk, (b) terjaga.

TABEL II

FITUR RANAH FREKUENSI

\begin{tabular}{|l|l|l|}
\hline \multicolumn{1}{|c|}{ Fitur Ranah Frekuensi } & \multicolumn{1}{c|}{ Pita Frekuensi } & Satuan \\
\hline Puncak frekuensi & VLF, LF, dan HF & $\mathrm{Hz}$ \\
\hline Daya absolut & VLF, LF, dan HF & $\mathrm{ms}^{2}$ \\
\hline Daya relatif & VLF, LF, dan HF & $\mathrm{ms}^{2}$ \\
\hline Daya logaritmik & VLF, LF, dan HF & $\log$ \\
\hline Daya ternormalisasi & LF, dan HF & - \\
\hline Total daya semua pita frekuensi & - & $\mathrm{ms}^{2}$ \\
\hline
\end{tabular}

metode Welch melibatkan pembagian sinyal menjadi beberapa segmen, mengambil periodogram yang dimodifikasi dari segmen ini, dan dirata-rata [14]. Parameter ranah frekuensi dihitung berdasarkan pita frekuensi dengan rentang standar untuk pita VLF $(0,00 \mathrm{~Hz}-0,04 \mathrm{~Hz}), \mathrm{LF}(0,04 \mathrm{~Hz}-0,15 \mathrm{~Hz})$, dan $\mathrm{HF}(0,15 \mathrm{~Hz}-0,40 \mathrm{~Hz})$ [15]. Dari proses ekstraksi fitur, seperti pada Tabel II, diperoleh enam belas fitur ranah frekuensi berdasarkan penelitian sebelumnya [15]. Gbr. 2 menunjukkan hasil ekstraksi metode ranah frekuensi. Terlihat dalam gambar bahwa rekaman kelas kantuk mempunyai komponen HF yang lebih tinggi, sedangkan rekaman kelas terjaga mempunyai komponen LF yang lebih tinggi.

Parameter statistik diturunkan dari seri NNI, seri perbedaan NNI berurutan $(\Delta \mathrm{NNI})$, dan seri HR [15]. NNI pada rekaman kelas kantuk terlihat lebih panjang daripada NNI pada rekaman kelas terjaga, seperti ditunjukkan pada Gbr. 3. Tabel III menunjukkan parameter statistik NNI dan detak jantung yang merupakan parameter EKG ranah waktu, yang terdiri atas delapan belas fitur.

Pada semua fitur diberlakukan normalisasi menggunakan minmax scaller sehingga fitur berada pada skala antara 0 dan 1 berdasarkan (1). Normalisasi bertujuan untuk menyamakan standar fitur dalam rentang tertentu. Fitur harus disamakan pada skala karena satuan dan amplitudo fitur-fitur yang digunakan dalam klasifikasi sangat berbeda antara satu dengan yang lain [16].

$$
f_{i, N}=\frac{f_{i}-\min \left(f_{i}\right)}{\max \left(f_{i}\right)-\min \left(f_{i}\right)}
$$

TABEL III

FITUR STATISTIK PARAMETER EKG RANAH WAKTU

\begin{tabular}{|c|c|c|}
\hline $\begin{array}{c}\text { Fitur Ranah } \\
\text { Waktu }\end{array}$ & Keterangan & Satuan \\
\hline NNI counter & jumlah NNI & - \\
\hline NNI mean & mean NNI & $\mathrm{ms}$ \\
\hline NNI $\min$ & NNI minimal & $\mathrm{ms}$ \\
\hline NNI $\max$ & NNI maksimal & $\mathrm{ms}$ \\
\hline NNI diff mean & mean $\Delta \mathrm{NNI}$ & $\mathrm{ms}$ \\
\hline NNI diff $\min$ & $\Delta \mathrm{NNI}$ minimal & $\mathrm{ms}$ \\
\hline NNI diff max & $\Delta$ NNI maksimal & $\mathrm{ms}$ \\
\hline HR mean & mean detak jantung & bpm \\
\hline HR $\min$ & detak jantung minimal & bpm \\
\hline $\mathrm{HR} \max$ & detak jantung maksimal & bpm \\
\hline HR std & standar deviasi seri detak jantung & bpm \\
\hline SDNN & standar deviasi NNI & $\mathrm{ms}$ \\
\hline RMSSD & akar rata-rata dari $\Delta$ NNI kuadrat & $\mathrm{ms}$ \\
\hline SDSD & standar deviasi $\Delta \mathrm{NNI}$ & $\mathrm{ms}$ \\
\hline NN50 & $\begin{array}{l}\text { jumlah } \Delta \text { NNI yang lebih besar dari } 50 \\
\text { ms }\end{array}$ & - \\
\hline pNN50 & $\begin{array}{l}\text { rasio antara NN50 dengan jumlah total } \\
\text { NNI }\end{array}$ & - \\
\hline NN20 & $\begin{array}{l}\text { jumlah } \Delta \text { NNI yang lebih besar dari } 20 \\
\text { ms }\end{array}$ & - \\
\hline pNN20 & $\begin{array}{l}\text { rasio antara NN20 dengan jumlah total } \\
\text { NNI }\end{array}$ & - \\
\hline
\end{tabular}

dengan $f_{i, N}$ adalah fitur ke- $i$ yang telah dinormalisasi, $f_{i}$ adalah fitur ke-i, sedangkan $\min \left(f_{i}\right)$ dan $\max \left(f_{i}\right)$ adalah nilai minimal dan maksimal fitur ke-i $[16]$.

\section{Pelatihan dan Pengujian Random Forest}

Random Forest adalah kumpulan atau ansambel dari Classification and Regression Trees (CART) yang dilatih pada set data dengan ukuran yang sama dengan set pelatihan, yang disebut bootstrap dan dibuat dari pengambilan sampel ulang secara acak pada set pelatihan itu sendiri [17]. Pelatihan Random Forest dilakukan dengan menggunakan $80 \%$ data dari setiap variasi segmen waktu. Sampel data pelatihan diambil dari $80 \%$ segmen secara acak dari setiap rekaman, sehingga 


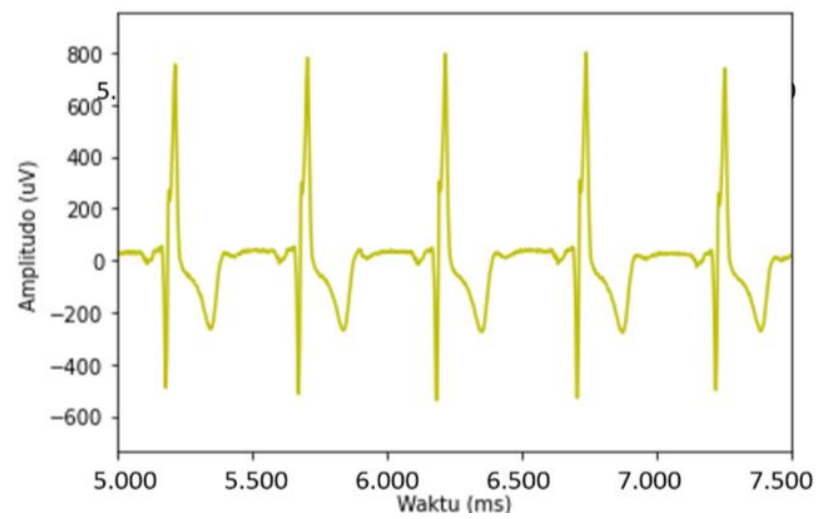

(a)

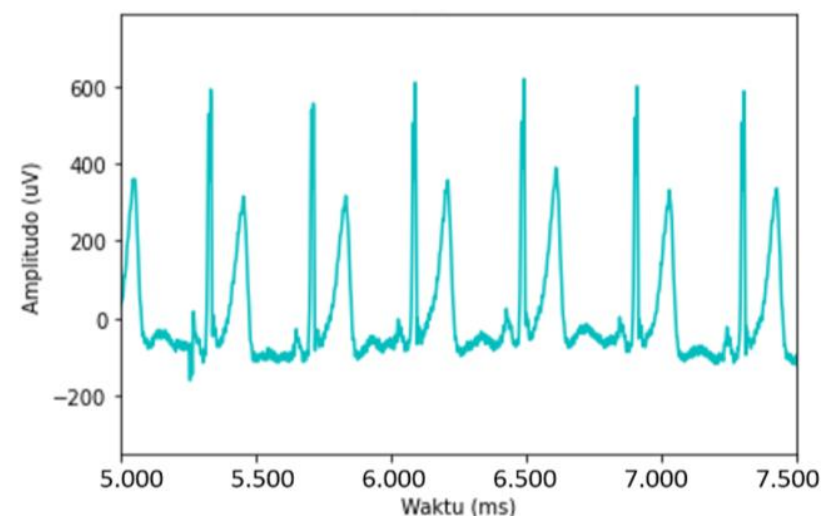

(b)

Gbr. 3 Grafik NNI rekaman, (a) kelas kantuk, (b) terjaga.

data pelatihan dan pengujian mempunyai rasio kelas terjaga dan kantuk yang sama. Tahap pelatihan terdiri atas tahap-tahap sebagai berikut [11].

1. Pembuatan pohon sejumlah $N$ estimator dari data pelatihan.

2. Penumbuhan pohon klasifikasi yang tidak dipotong pada setiap sampel bootstrap,. Pada setiap nodus, daripada memilih pemisahan terbaik di antara semua prediktor, diambil sampel $m$ _try acak dari prediktor dan dipilih pemisah terbaik di antara variabel tersebut.

3. Prediksi data baru dengan mengumpulkan prediksi dari semua pohon (yaitu suara terbanyak untuk klasifikasi).

Random Forest divalidasi menggunakan akurasi Out-of-Bag (OOB), yaitu data yang tidak termasuk dalam sampel bootstrap. Pengujian Random Forest dilakukan dengan data pengujian sejumlah $20 \%$ dari data keseluruhan yang tidak digunakan dalam proses pelatihan.

Random forest dapat digunakan untuk menentukan peringkat fitur berdasarkan pengaruhnya dalam klasifikasi. Kepentingan fitur dinilai oleh indeks kriteria Gini impurity. Indeks Gini adalah ukuran kekuatan prediksi variabel pada regresi atau klasifikasi. Gini yang rendah memiliki arti sebuah fitur mempunyai peran yang bagus dalam memisahkan data ke dalam dua kelas. Oleh karena itu, indeks Gini dapat digunakan untuk membuat peringkat kepentingan fitur pada klasifikasi [17].

Kinerja sistem deteksi ini ditentukan menggunakan tiga parameter kinerja, yaitu akurasi, sensitivitas, dan specificity. Akurasi menunjukkan kedekatan antara nilai prediksi dengan nilai aktual, yaitu tingkat kesuksesan Random Forest mengklasifikasi kelas terjaga dan kantuk. Sensitivitas menunjukkan True Positive Rate (TPR) atau tingkat kesuksesan Random Forest mendeteksi kelas kantuk. Specificity menunjukkan False Positive Rate (FPR) atau tingkat kesuksesan Random Forest mendeteksi kelas terjaga. Akurasi diperoleh dari (1), sensitivitas diperoleh dari (2), dan specificity diperoleh dari (3).

$$
\begin{gathered}
\text { Akurasi }=\frac{T P+T N}{T P+F P+T N+F N} \times 100 \% \\
\text { Sensitivitas }=\frac{T P}{T P+F N} \times 100 \%
\end{gathered}
$$

TABEL IV

KINERJA SISTEM DETEKSI DENGAN VARIASI JUMLAH ESTIMATOR PADA RANDOM FOREST

\begin{tabular}{|c|c|c|c|c|}
\hline $\begin{array}{c}\text { Jumlah } \\
\text { Estimator }\end{array}$ & $\begin{array}{c}\text { Akurasi } \\
(\%)\end{array}$ & $\begin{array}{c}\text { Sensitivitas } \\
(\boldsymbol{\%})\end{array}$ & $\begin{array}{c}\text { Specificity } \\
(\boldsymbol{\%})\end{array}$ & $\begin{array}{c}\text { OOB } \\
(\%)\end{array}$ \\
\hline 10 & 84,74 & 88,91 & 78,79 & 70,40 \\
\hline 20 & 85,20 & 91,09 & 76,79 & 75,55 \\
\hline 30 & 86,21 & 93,59 & 75,67 & 76,84 \\
\hline 40 & 86,76 & 93,75 & 76,79 & 78,49 \\
\hline 50 & 86,76 & 93,75 & 76,79 & 77,94 \\
\hline 60 & 85,66 & 92,50 & 75,89 & 79,23 \\
\hline 70 & 85,29 & 91,25 & 76,79 & 78,68 \\
\hline 80 & 85,66 & 91,25 & 77,68 & 79,04 \\
\hline 90 & 86,03 & 91,88 & 77,68 & 80,33 \\
\hline 100 & 86,03 & 91,25 & 78,57 & 79,04 \\
\hline
\end{tabular}

$$
\text { Specificity }=\frac{T N}{F P+T N} x 100 \%
$$

dengan TP adalah true positive, yaitu jumlah data EKG kantuk terdeteksi benar; FP adalah false positive, yaitu jumlah data EKG kantuk terdeteksi salah; $F N$ adalah false negative, yaitu jumlah data EKG terjaga terdeteksi salah; dan $T N$ adalah true negative, yaitu jumlah data EKG terjaga terdeteksi benar [18].

\section{HASIL DAN PEMBAHASAN}

Pada makalah ini dipaparkan sistem deteksi kantuk meggunakan elektrokardiogram dan algoritme Random Forest. Prinsip dari algoritme Random Forest adalah ansambel yang terdiri atas sejumlah sistem klasifikasi individu, yaitu decision tree yang masing-masing menentukan hasil klasifikasi individu, dengan hasil akhir dari model ansambel Random Forest ditentukan oleh suara terbanyak dari masing masing decision tree. Struktur Random Forest mempunyai parameter yang perlu ditentukan sebelum dilakukannya pelatihan. Pada makalah ini, dilakukan variasi jumlah estimator (jumlah decision tree yang digunakan), seperti pada Tabel IV, serta variasi max feature (jumlah maksimal fitur acak yang dipertimbangkan di setiap nodus), seperti pada Tabel V, untuk menentukan parameter terbaik. Kualitas percabangan pada 


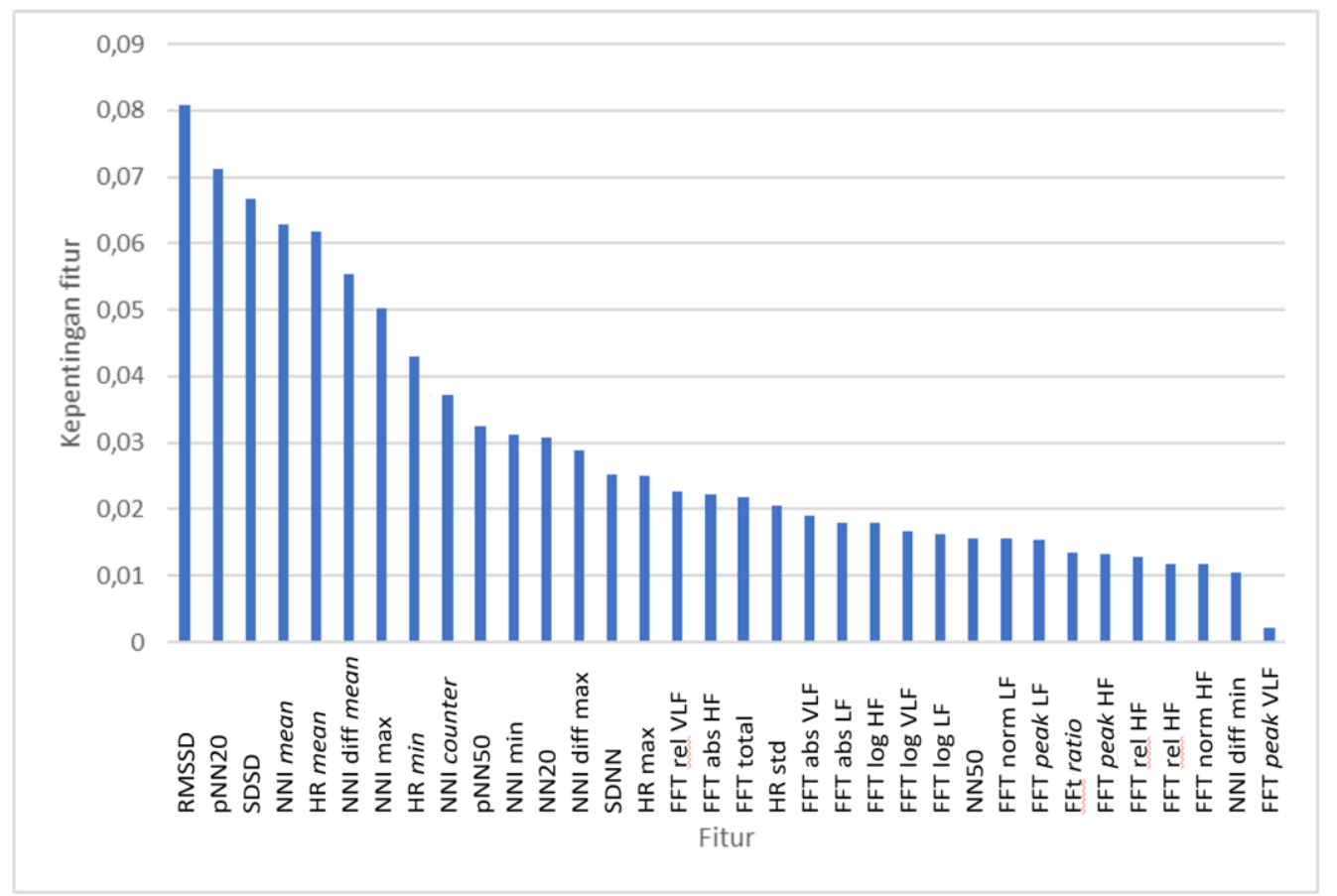

Gbr. 4 Grafik kepentingan fitur.

TABEL V

HASIL VARIASI MAX FEATURES PADA RANDOM FOREST

\begin{tabular}{|c|c|c|c|c|}
\hline $\begin{array}{c}\text { Max } \\
\text { Feature }\end{array}$ & $\begin{array}{c}\text { Akurasi } \\
(\%)\end{array}$ & $\begin{array}{c}\text { Sensitivitas } \\
(\%)\end{array}$ & $\begin{array}{c}\text { Specificity } \\
(\%)\end{array}$ & $\begin{array}{c}\text { OOB } \\
(\%)\end{array}$ \\
\hline 0,2 & 86,76 & 90,00 & 82,14 & 80,70 \\
\hline 0,3 & 87,87 & 93,13 & 80,36 & 79,60 \\
\hline 0,4 & 86,40 & 91,88 & 78,57 & 79,78 \\
\hline 0,5 & 87,50 & 91,25 & 82,14 & 78,31 \\
\hline
\end{tabular}

pohon ditentukan dengan Gini impurity. Parameter lain seperti urutan kepentingan fitur serta kombinasi gabungan fitur ditentukan dalam makalah ini. Kinerja model dinilai menggunakan parameter akurasi, sensitivitas, specificity, dan akurasi OOB. Akurasi, sensitivitas, dan specificity yang digunakan merupakan rata-rata dari pelatihan dan pengujian, sedangkan akurasi OOB diperoleh dari hasil pengujian.

Jumlah estimator menunjukkan banyaknya pengklasifikasi pohon (decision tree) yang digunakan untuk membangun ansambel Random Forest. Variasi ini bertujuan untuk menemukan jumlah estimator yang tepat untuk sistem deteksi kantuk. Hasil variasi jumlah estimator disajikan pada Tabel IV. Kinerja terbaik rata-rata akurasi, sensitivitas, dan specificity diperoleh pada jumlah estimator 40 dan 50 dengan nilai akurasi, sensitivitas, dan specificity berturut-turut sebesar $86,76 \%, 93,75 \%$, dan 76,79\%. Dari hasil tersebut, terlihat bahwa semakin banyak pohon yang digunakan, semakin baik kinerja Random Forest. Namun, setelah variasi jumlah estimator 50, tidak terdapat kenaikan kinerja.

Nilai max features menunjukkan banyaknya nilai maksimal fitur acak yang dapat diambil pada setiap titik pemisah setiap individu pohon Random Forest. Dari Tabel V diperoleh kinerja terbaik pada akurasi, sensitivitas, dan specificity pada nilai 0,3 , dengan nilai akurasi, sensitivitas, dan specificity berturut-turut $87,87 \%, 93,13 \%$, dan 80,36\%. Max features 0,3 mengandung arti bahwa setiap individu pohon hanya dapat mempertimbangkan maksimal $30 \%$ fitur pada setiap nodus untuk dijadikan pemisah.

Urutan kepentingan fitur bertujuan untuk menilai kontribusi setiap fitur dalam menentukan hasil klasifikasi. Semua fitur ranah waktu dan ranah frekuensi dijadikan masukan Random Forest. Jumlah estimator atau pohon yang digunakan sebanyak lima puluh dan max feature 0,3. Pada Gbr. 4 ditunjukkan fitur yang berperan paling penting sampai paling tidak penting dalam menentukan hasil deteksi. Nilai kepentingan fitur didasarkan pada tingkat kesuksesan fitur tersebut mengurangi Gini impurity. Pengurutan fitur-fitur berdasarkan kepentingannya bermanfaat untuk menentukan fitur yang lebih efisien dalam menjalankan klasifikasi. Dari eksperimen diketahui bahwa fitur yang mempunyai tingkat kepentingan paling tinggi adalah RMSSD dan fitur yang mempunyai tingkat kepentingan paling rendah adalah FFT peak VLF. Tingkat kepentingan fitur lainnya berada di antara kedua fitur tersebut, seperti ditunjukkan pada Gbr. 4.

Akurasi sistem deteksi yang menggunakan variasi kombinasi fitur dan panjang segmen yang berbeda ditunjukkan pada Gbr. 5. Kombinasi ini dilakukan berdasarkan urutan kepentingan fitur seperti yang ditunjukkan Gbr. 4. Kombinasi cfl terdiri atas satu fitur, yaitu fitur dengan kepentingan tertinggi, RMSSD. Kombinasi $c f 2$ terdiri atas dua fitur, yaitu fitur dengan kepentingan tertinggi (RMSSD) dan fitur dengan kepentingan tertinggi kedua (pNN20). Dengan cara yang sama, cf3 terdiri atas tiga fitur dengan kepentingan tertinggi pertama sampai ketiga, yaitu RMSSD, pNN20, dan SDSD. Kombinasi cf4 sampai dengan cf33 disusun dengan cara yang serupa. 


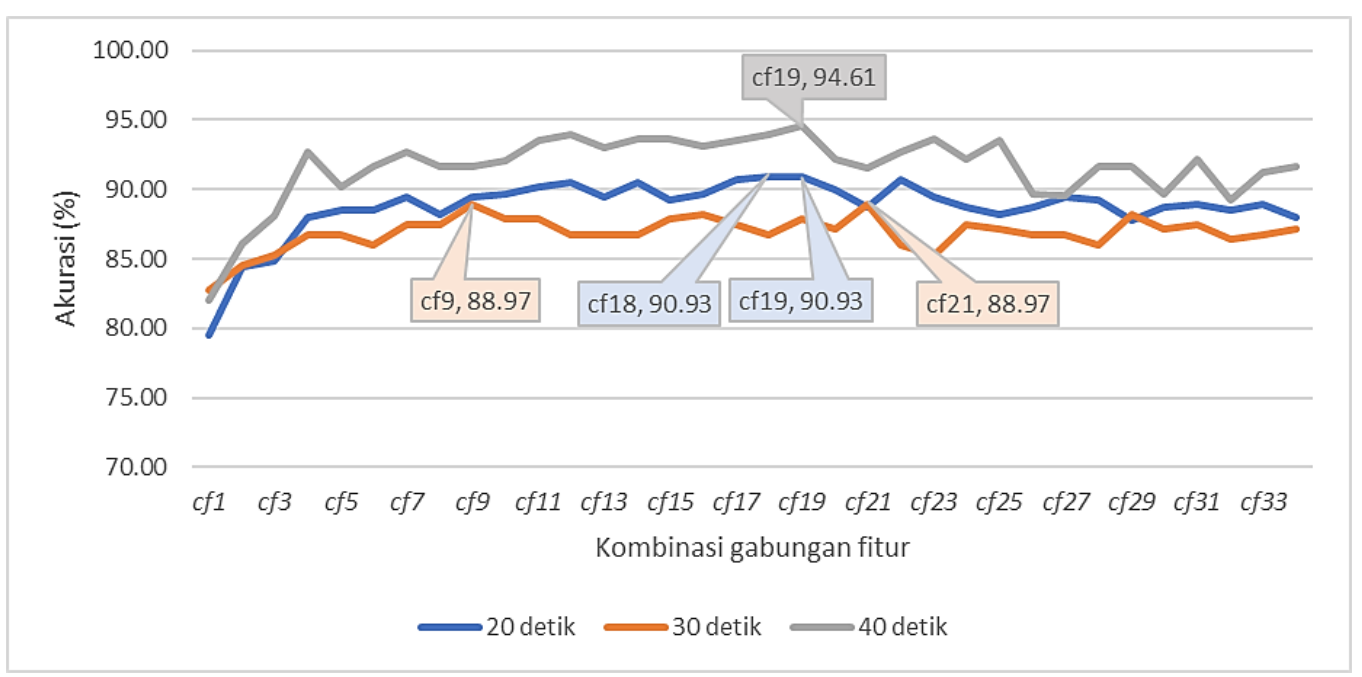

Gbr. 5 Akurasi sistem deteksi pada kombinasi fitur dan panjang segmen.

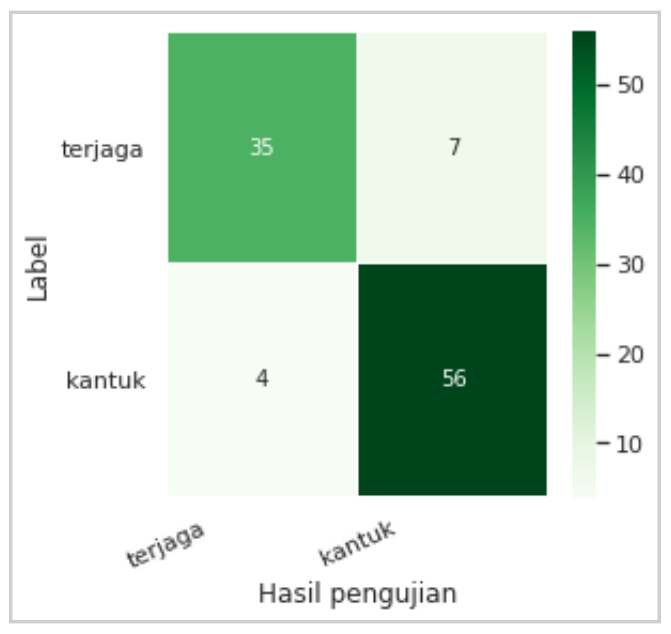

Gbr. 6 Grafik confusion matrix model Random Forest terbaik.

Dengan demikian, cf33 merupakan kombinasi dari semua fitur. Akurasi dengan panjang segmen (20, 30, dan 40 detik) pada semua kombinasi tersebut juga dipaparkan pada Gbr. 5 .

Seperti ditunjukkan pada Gbr. 5, terlihat bahwa dengan menggabungkan fitur dengan urutan kepentingan tertinggi, dihasilkan kenaikan akurasi. Namun, akurasi mengalami penurunan pada tingkat tertentu. Akurasi terbaik untuk panjang segmen 20 detik adalah 90,93\%, pada kombinasi fitur cfl 18 dan cf19. Akurasi terbaik pada segmen 30 detik adalah 88,97\% pada $c f 9$ dan $c f 21$, sedangkan akurasi terbaik pada segmen 40 detik adalah $94,61 \%$ pada $c f 19$. Dari hasil kombinasi gabungan fitur dan panjang segmentasi, diperoleh sistem deteksi kantuk dengan kinerja terbaik adalah pada $c f 19$, yang terdiri atas sembilan belas fitur dan segmentasi 40 detik. Kinerja sistem deteksi keadaan ini adalah akurasi 94,61\%, sensitivitas 96,67\%, dan specificity 91,67\%. Akurasi menunjukkan kemampuan model dalam mendeteksi kelas terjaga dan kantuk dengan benar. Dengan demikian, model dengan akurasi terbaik adalah kombinasi gabungan fitur cf19 dan segmentasi 40 .

Pada panjang segmen 40 detik terdapat 510 segmen data, sehingga didapatkan data pelatihan 408 segmen dan data pengujian 102 segmen, dengan perbandingan $80 \%$ dan $20 \%$.
Hasil pengujian ditunjukkan pada Gbr. 6, yaitu diperoleh 56 true positive, 35 true negative, tujuh false positive, dan empat false negative dari total data pengujian 102 segmen. Hasil ini menunjukkan bahwa sistem deteksi dapat mengidentifikasi keadaan kantuk dengan benar sebanyak 56 kali, mengidentifikasi keadaan terjaga dengan benar sebanyak 35 kali, salah mendeteksi kelas kantuk sebanyak empat kali, dan salah mendeteksi kelas terjaga sebanyak tujuh kali.

\section{KESIMPULAN}

Pada makalah ini telah dibuat suatu model sistem deteksi kantuk menggunakan ansambel Random Forest dengan EKG. Masukan sistem deteksi kantuk berasal dari fitur yang diekstraksi dari rekaman EKG dengan metode ranah waktu dan ranah frekuensi. Sebelum dilakukan ekstraksi fitur, rekaman EKG difiltrasi menggunakan filter FIR dan kompleks QRS dideteksi menggunakan algoritme Hamilton segmenter. Hasil deteksi kompleks QRS digunakan untuk menentukan NNI yang diperlukan untuk ekstraksi fitur.

Pengembangan model deteksi kantuk Random Forest dilakukan dengan optimasi variasi struktur Random Forest. Variasi yang dilakukan adalah variasi jumlah estimator, jumlah max features, mengurutkan fitur berdasarkan kepentingannya dalam menentukan keputusan Random Forest, serta variasi masukan kombinasi gabungan fitur. Pelatihan Random Forest menghasilkan model dengan kinerja terbaik dengan segmentasi 40 detik dan kombinasi gabungan fitur cf19, dengan rata-rata akurasi $94,61 \%$, sensitivitas $96,67 \%$, dan specificity $91,67 \%$.

\section{REFERENSI}

[1] WHO, Global Status Report on Road Safety 2018, Geneva, Switzerland: World Health Organization, 2018.

[2] J. He, W. Choi, Y. Yang, J. Lu, X. Wu, dan K. Peng, "Detection of Driver Drowsiness Using Wearable Devices: A Feasibility Study of the Proximity Sensor," Applied Ergonomics, Vol. 65, hal. 473-480, Nov. 2017.

[3] J.D. Slater, "A Definition of Drowsiness: One Purpose for Sleep?" Med. Hypotheses, Vol. 71, No. 5, hal. 641-644, Nov. 2008.

[4] K. Kaida, M. Takahashi, T. Åkerstedt, A. Nakata, Y. Otsuka, T. Haratani, dan K. Fukasawa, "Validation of the Karolinska Sleepiness Scale against 
Performance and EEG Variables," Clin. Neurophysiol., Vol. 117, No. 7, hal. 1574-1581, Jul. 2006.

[5] A. Shahid, K. Wilkinson, S. Marcu, dan C.M. Shapiro, Eds., STOP, THAT and One Hundred Other Sleep Scales, New York, USA: Springer Science \& Business Media, 2012.

[6] J. Vicente, P. Laguna, A. Barta, dan R. Bailón, "Drowsiness Detection Using Heart Rate Variability," Med. Biol. Eng. Comput., Vol. 54, No. 6, hal. 927-937, Jan. 2016.

[7] B. Singh dan N. Bharti, "Software Tools for Heart Rate Variability Analysis," Int. J. Recent Sci. Res., Vol. 6, No. 4, hal. 3501-3506, Apr. 2015 .

[8] G.S. Wagner dan D.G. Strauss, Marriott's Practical Electrocardiography, Philadelpia, USA: LWW, 2013.

[9] O. Maftukhaturrizqoh, "Deteksi Kantuk Menggunakan Jaringan Saraf Tiruan dengan Fitur Statistik RR Elektrokardiogram," Skripsi, Universitas Sebelas Maret, Surakarta, Indonesia, Jul. 2018.

[10] A. Shalihah, "Sistem Deteksi Kantuk Menggunakan Jaringan Saraf Tiruan (JST) dan Particle Swarm Optimization," Skripsi, Universitas Sebelas Maret, Surakarta, Indonesia, Sep. 2019.

[11] A. Liaw dan M. Wiener, "Classification and Regression by randomForest," R News, Vol. 2/3, hal. 18-22, Des. 2002.

[12] Q. Massoz, T. Langohr, C. François, dan J.G. Verly, "The ULg Multimodality Drowsiness Database (Called DROZY) and Examples of
Use," 2016 IEEE Winter Conf. Appl. Comput. Vis. (WACV), 2016, hal. 17.

[13] P. Hamilton, “Open Source ECG Analysis," Comput. Cardiol., 2002, hal. 101-104.

[14] K.K. Parhi dan M. Ayinala, "Low-complexity Welch Power Spectral Density Computation," IEEE Trans. Circuits Syst. I: Regul. Pap., Vol. 61, No. 1, hal. 172-182, Jun. 2013.

[15] P. Gomes, P. Margaritoff, dan H. Silva, "pyHRV: Development and Evaluation of an Open-source Python Toolbox for Heart Rate Variability (HRV)," Proc. Int. Conf. Electric., Electron. Comput. Eng. (IcETRAN), 2019, hal. 822-828.

[16] Y. Isler, "Discrimination of Systolic and Diastolic Dysfunctions Using Multi-layer Perceptron in Heart Rate Variability Analysis," Comput. Biol. Med., Vol. 76, hal. 113-119, Sep. 2016.

[17] A. Sarica, A. Cerasa, dan A. Quattrone, "Random Forest Algorithm for the Classification of Neuroimaging Data in Alzheimer's Disease: A Systematic Review,” Front. Aging Neurosci., Vol. 9, hal. 1-12, Okt. 2017.

[18] M. Ghaderzadeh, R. Fein, dan A. Standring, "Comparing Performance of Different Neural Networks for Early Detection of Cancer from Benign Hyperplasia of Prostate," Appl. Med. Inform., Vol. 33, No. 3, hal. 45-54, Sep. 2013. 